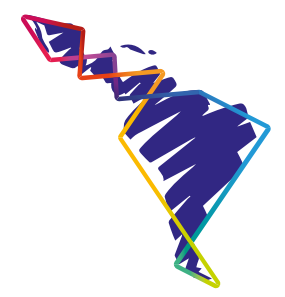

\title{
Exilio, discurso y abordaje de fuentes orales: Chilenos en Costa Rica
}

\author{
Exile, speech and approach from \\ oral sources: Chileans in Costa Rica
}

\section{Exílio, discurso e abordagem de fontes orais: chilenos na Costa Rica}

Ronald Obando Brenes ${ }^{1}$

\begin{abstract}
Resumen
La investigación del exilio chileno en Costa Rica ha deparado una abundante compilación de fuentes orales: relatos, experiencias y testimonios que se corresponden con el hecho histórico que marcó el devenir de Chile desde el golpe de Estado en 1973. Mucha de la población exiliar permaneció en Costa Rica desde entonces. De las conversaciones y entrevistas se intercalan potenciales aspectos de análisis discursivo y semiótico que se entretejen a la memoria entre recuerdos, olvidos y silencios; nudos que la muestra intenta presentar.
\end{abstract}

Palabras clave: Exilio, memoria, discurso, semiótica.

\begin{abstract}
The investigation of the Chilean exile in Costa Rica has produced an abundant compilation of oral sources: stories, experiences and testimonies that correspond to the historical fact that marked the evolution of Chile since the coup d'état in 1973. Much of the exile population remained in Costa Rica since then. From the conversations and interviews, potential aspects of discursive and semiotic analysis are interspersed that interweave the memory between memories, forgetfulness and silences; knots herein attempted to be presented.
\end{abstract}

Keywords: Exile; Memory; Speech; Semiotics.

1 Profesor, investigador del Instituto de Estudios Latinoamericanos, Universidad Nacional, Costa Rica. Profesional en el área de relaciones internacionales y estudios latinoamericanos. ORCID: https://orcid. org/0000-0002-1000-5329 


\section{Resumo}

A investigação do exílio chileno na Costa Rica produziu uma compilação abundante de fontes orais: histórias, experiências e testemunhos que correspondem ao fato histórico que marcou a evolução do Chile desde o golpe de Estado de 1973. Grande parte da população exilada permaneceu na Costa Rica desde aquela época. A partir das conversas e entrevistas, aspectos potenciais da análise discursiva e semiótica são intercalados, entrelaçando a memória entre memórias, esquecimentos e silêncios; nós que a amostra tenta apresentar.

Palavras-chave: Exílio; Memória; Fala; Semiótica.

\section{Subjetivar los discursos}

Hojas de información, cafés, abrazos, sonrisas y hasta lágrimas. A muchas sensaciones se avocaron los propios testigos del exilio durante la práctica de su oralidad. La delimitación de las imágenes chilenas rebrotó en la Centroamérica de comienzos de los años setenta.

Estos actores de la política, de las artes, de la academia, de la cotidianidad revolucionaria popular, a su llegada, encontraron, en un San José de tonos sepia, su momento de reencuentro en el exilio; descrito como difuso, convulso, irrepetible para estos transterrados seres que no creían mirarse en otro contexto distinto que no fuera Chile. Una primera mirada al exilio lo deja entrever el hijo de los actores escénicos Marcelo Gaete y Sara Astica a su llegada:

Nosotros no teníamos ninguna imagen de Costa Rica, podríamos haberla tenido por una cuestión familiar biográfica, habíamos leído algunos folletos; nos imaginábamos un país tropical, pero con una noción abstracta muy deshistorizada, idealizada de lo que podía ser. Llegamos un 5 de mayo, al llegar a la ciudad la vimos pequeña. (Marcelo Gaeta Astica, hijo de exiliados, comunicación personal, 14 de febrero 2018).

En adición al recuadro anterior, la pregunta que el primer exiliado en Costa Rica hizo fue: "Y ahora si Arenas, ¿qué vas a hacer aqu??. Acto seguido, desenfundó el arma de guerra que tenía oculta tras una funda. Y en aquel país de mitos pacifistas, el sujeto con un lógico atino de satisfacer su hambre física primero, política después, como exiliado se puso a tocar música chilena en el Parque Central capitalino; sitio que para aquel era una plaza (de armas) como se le conoce en su país (Entrevista personal a Patricio Arenas, 2017año). ¿A quién?

Así, poco a poco, las expresiones de solidaridad fueron brotando casi de la nada. Sin embargo, el hecho histórico de esta presencia tampoco se debió a la casuística de los hechos o a la serendipia, sino que se marcó una coyuntura interesante, antecedida 
de una voluntad política para acoger a este grupo de personas; coyuntura que sería irrepetible, como lo describe el sociólogo Daniel Camacho Monge (Comunicación personal sobre red de apoyo, 30 de marzo 2017fecha):

Les cuento que Pepe Figueres² decía: "El primer deber del exiliado es sobrevivir", entonces eso era lo que hacíamos nosotros (COMO TICOS); ayudar a los chilenos a sobrevivir; que tuvieran plata para pagar un apartamento, comer y vestirse; ya eso era importantísimo.

Con su éxodo, los chilenos escribieron un capítulo en la biblia de los exilios globales. Y es que la heurística del exilio posee, como un punto y aparte, el estudio del contenido, la búsqueda de su contención y la conmutación propia de las narrativas a las que aluden.

Antes que catalogarlas con cualquier epíteto, en las narraciones del exilio sí resultan notables las transformaciones particulares más recientes del viaje vivido por cada sujeto en su exilio. Esto, precisamente, influye en componentes del discurso como la estética, la dialéctica y las relaciones sintagmáticas; palabras que tienden a resaltarse por un orden, a exaltar ciertos énfasis y, entre tanto, a propiciar una distinción particular del discurso-retórica con respecto a otros exilios (las narrativas en plural).

Ciertamente, al hablar de exilios, suelen ocurrir particularidades especiales que el historiador Mario Oliva Medina (2019), así nos recuerda:

La memoria está hecha en base al [sic] conocimiento. La historia también está hecha en base a [sic] la memoria, al testimonio, pero las tres cosas son diferentes. Hay personas que recuerdan cosas, otras omiten, otras borran. Había algunas personas que decían - "no, yo no quiero hablar de la tortura" -. A lo que respondíamos: - Muy bien, ¿de qué quiere hablar?

Entonces, hay que construir una memoria de su propio exilio, de su venida, de su inserción, etc. Hay que contrarrestar eso con otras fuentes y, precisamente, tratar de ver que esa memoria no es la historia, sino construcciones personales. Además, están totalmente mediatizadas por el tiempo, por la sociabilidad, por la inserción al país.

No hay ningún chileno, -esto debe ser como una característica de los chilenos-, que no haya dicho "sí, nosotros vinimos, pero aportamos mucho al país" o, "nos quedamos porque también dimos todo lo que teníamos que dar".

2 Expresidente de Costa Rica, 1970-74. 
$\mathrm{Y}$ a veces uno piensa que esas pueden ser como formas de ocultar otros procesos, otras historias, otras memorias, y de cómo también se va desvaneciendo la historia del exilio y se va construyendo otra. (Entrevista a Mario Oliva por Ángelo Narváez, en sitio razacosmica.cl)

Por su parte, un ejemplo de ese borramiento voluntario, visible y tácito a la vez se manifiesta en la narración de una exiliada sobre su experiencia de prisión y tortura:

Las cosas que yo pasé en Chile las he hablado con detalle solo dos veces: uno; cuando se iba a hacer acá un juicio ético contra Pinochet, entonces el fiscal que era un abogado amigo costarricense iba a hacer las acusaciones, ahí yo tuve que prestar las declaraciones y declaraciones contundentes porque era un juicio al dictador; y la segunda vez que di mi experiencia pormenorizada de lo que fueron mis dos años de tortura y prisión fue cuando se elaboró el informe Valech; en donde se documentaban los casos de quienes habíamos pasado por esa experiencia. Y no lo he hablado nunca más. (Comunicación personal con Tatiana Tregueart, exiliada, trabajadora social, 24 de marzo 2017)

Por contraste, si en la actualidad (2019) volviéramos a realizar otra entrevista a cada sujeto mencionado, se podría lanzar una hipótesis: muchas de las narrativas variarían respecto a su toma original. Tal vez sería más en su forma, que en contenido. Pero, ciertamente, no se podrían dejar de percibir a otras formas del decir que gritan sus motivaciones: entre ellas los silencios, los olvidos; la caracterización particular de las narrativas, las estructuras del relato, las posiciones narrativas, los juicios de valor y, por qué no, hasta la autocensura. Sobre esta serie de posturas mutables, el cineasta Pedro Zurita recoge su parecer:

Si tu preguntas de esa percepción que tengo; más que nada lo veo en la adaptación que han tenido los chilenos acá, que se sienten muy a gusto, se olvidaron todos estos perjuicios que yo podía haber tenido en esa época y que ellos también los tenían, que eran perjuicios propios de la adaptación; de creer que lo que uno dejó era mejor, y por eso; lo que dejaste ya no existe. (Pedro Zurita, cineasta, exiliado, comunicación personal, 4 de agosto, 2017)

Desde otro orden de ideas, la historiadora Marina Franco (2007, p. 40), desde las narrativas nos introduce a otras maneras de subjetivación al mencionar que "la entrevista, como documento oral, no es el resultado de una narración del entrevistado (aunque el 'contenido' lo narre él); ni de las preguntas del entrevistador (aunque las respuestas estén condicionadas por lo que éste plantee y la relación que proponga); al contrario, es el producto de una relación”. 
En ese sentido, la entrevista es una narrativa conversacional que sólo se comprende entendiendo las relaciones dentro de esa estructura cerrada que ella representa. Por tanto, el testimonio de una situación inducida en una entrevista oral no puede ser analizado de la misma manera que un testimonio espontáneo (no solicitado) en presente o en pasado.

\section{Figura 1}

Recopilación de oralidades, dinámica de entrevistas

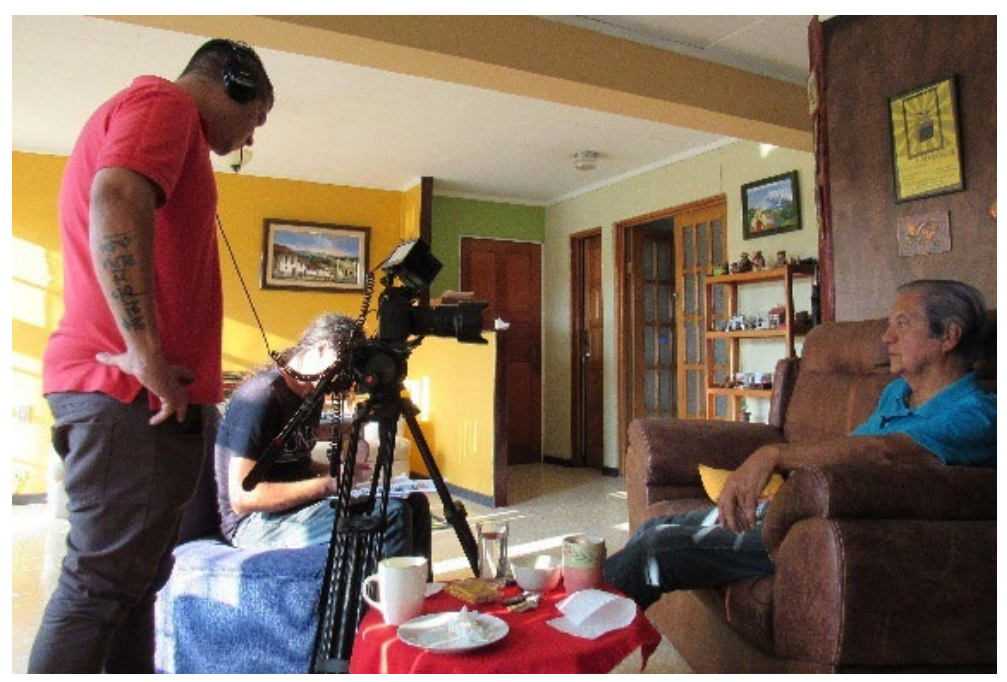

Fuente: Archivo del proyecto Voces y rostros del exilio chileno en Costa Rica.

Aparece, así, la implicación de un proceso de reconocimiento subjetivo de la alteridad o, mejor dicho, una intersubjetivación, según lo llamaría Husserl y Webber. Empero, por más recursos o tácticas de acercamiento étnico-metodológico hacia el otro que se empleen, el investigador indirectamente dejaría también su huella latente y sus juicios en la sincronía de estas conversaciones. La posición discursiva y la cualidad semiótica de su comunicación tienden a marcar un punto de referencia en el discurso expreso y se posesionan entre los intereses particulares y los convenidos; entre el habla y la escucha. A esta situaciones Marina Franco (2007, p. 42) agrega:

El problema central que en general se le ha imputado a la fuente oral es su subjetividad, tanto la del entrevistado como la del entrevistador. En realidad, la primera subjetividad es la del investigador mismo, que presenta un tema de investigación, formula preguntas, guía una entrevista y sus condiciones de desarrollo, representa a una institución, sector social, generación, etc. Todos estos factores se presentan al entrevistado y condicionan su discurso creando una narrativa $\mathrm{X}$, que sería otra en 
condiciones distintas. Por eso, también nuestra propia intervención condiciona la construcción discursiva sobre el exilio, la posición adoptada por el narrador o los elementos que se omiten. Por ejemplo, es probable que la diferencia generacional entre entrevistador y entrevistado influya para silenciar ciertos elementos y/o magnificar otros de la experiencia vivida.

Y es, precisamente, en ese momento, cuando la influencia relativa del lugar "desde" precisa el intercambio de conocimientos como límites al engranaje de los discursos. Vale mencionar que la confluencia de los saberes tiene su origen desde su creación epistemológica, según describe Boaventura de Soussa Santos (2009). Por tanto, conocer los exilios, desde sus caracterizaciones y contextualizaciones actuales, nunca es lo mismo que haberlo hecho de primera mano; hace cuatro décadas. En referencia a lo anterior, el psicólogo exiliado Armando Campos Santelices narra una condición particular en torno a las formas de comunicación cultural de los chilenos:

En mi caso, ya tengo 40 años aquí y mis posibilidades de aporte; de acuerdo con mis capacidades e intereses; han sido diversas, y en cierto modo han venido creciendo. Otra cosa que ayuda mucho para aportar es conocer el medio, hay muchas cosas que se van modificando cuando estamos en un país diferente. Algo que parece trivial, pero que considero muy significativo es que los chilenos nos vemos obligados a modificar nuestra comunicación humorística. La cultura chilena se caracteriza por la comunicación punzante con una gran utilización de paradojas e ironías. (Armando Campos Santelices, exiliado, comunicación personal, 21 de abril de 2017)

De forma semejante, el editor exiliado Eduardo Montecinos Cisterna rememora nociones cambiantes en torno al paso de millares de chilenos por Costa Rica:

... era el 74 o 75; entonces aquí llegaron 15, 18..., 20000 chilenos, y nos quedamos 12 000; ahora andamos los 4000,5000, porque ya no cuentan los hijos que nacieron aquí, que son chilenos. (Eduardo Montesinos, exiliado, comunicación personal, 28 de agosto 2017)

De tal manera, la subjetividad expresa en las narraciones también es observada en la dinámica de su complejidad o sencillez con que cada exiliado aborde la conversación. Por un lado, está la naturalidad distendida de las palabras que se expresaban muy coloquialmente en medio de un café; por ejemplo (lo que es cercano al llamado discurso informativo y referencial). Y, por otro lado, estaban los sujetos que se tomaban su debido tiempo para esbozar un panorama más denso, analítico e interpretativo; estos se acercaban a una elaboración retórico-oratoria. De este último caso, se recoge un ejemplo de la entrevista realizada a Francisco Rojas Aravena, académico exiliado, quien menciona sus razones específicas para escoger Costa Rica: 
Yo estaba terminando de estudiar en la Universidad, en ese momento no sabía nada de Costa Rica prácticamente. Me dediqué a mirar, y de las cosas que me llamaron la atención, fue particularmente en el ámbito económico. En ese momento, Costa Rica tenía una inflación de alrededor de un $6 \%$ anual, y del cual se concentraba el $5 \%$ en el segundo semestre, -lo que tenía que ver con la cosecha del café-, el tiempo donde se recogía el café y se pagaba en efectivo, y la segunda cosa, que también me llamaba la atención, era la estabilidad monetaria con el valor del dólar, estable a lo largo del tiempo. (Francisco Rojas Aravena, exiliado, comunicación personal, 10 de marzo 2017)

Asimismo, conviene señalar que para conocer la presencia del exilio en dichas personas, la entrevista se aprovechó para visibilizar la evolución, transformación y conformación cultural mediante la aplicación de técnicas autobiográficas y biográficas, derivadas del método etnográfico.

De esta manera, cada relato inicia con una autopresentación del exiliado; la estructura abierta permite catalogar los relatos como historias de vida referenciadas por el exilio. El instrumento aplicado contenía tres momentos; (a) el antes del golpe de Estado; (b) el momento del golpe y (c) el después del golpe (su exilio).

Desde un punto de vista metodológico, interesó conocer, de primera mano, la génesis del suceso-exilio; las consecuencias, la mutación y transformaciones del fenómeno a través de las expresiones subjetivas. Se sistematizaron temas sobre sociabilidades, tipos de solidaridad, aproximaciones a las coyunturas sociales y políticas, conceptualizaciones básicas sobre el exilio, aportes del exilio, así como algunos aprendizajes de las experiencias.

Del mismo modo, otro asunto de la revisión oral es mantenerse atentos a los minúsculos detalles de una palabra que se escapó, un silencio inesperado, o una mirada entrecortada; estas condiciones muchas veces son claves imprescindibles para comprender el trasfondo de todo un relato. Esta literalidad se expresa en la lectura de un poema por su propia autora:

Vamos a ver si puedo porque este libro me duele mucho cuando lo leo. (Silencio...); voy a leer este del abuelo, "El abuelo grande":

"Todos los lunares que salpican de polen en mi cuerpo y de risa tu boca, al jugar en mi espalda, vienen del abuelo grande, alto, rubio, buen mozo, terrateniente, latifundista, serenense, cabrón, padre quizás de otros bastardos, miserable bandido, acaudalado, abusador, todas estas motitas de pecas juguetonas, que más de un poema 
sobre estrellas y arco iris, inspiro tus besos, vienen de cromosomas tramposos, con memoria cibernética que hablan de conquista, despojo, robo, hambre, esta gracia que según tú, me acompaña, me adorna, me alegra, vienen del llanto, de la pena, del amor ultrajado, no compartido por ser ella deshuesadora de duraznos, costurera por contrato, sombrerera de ilusiones y el tan rico, alto, rubio, buen mozo, terrateniente, latifundista y cabrón". (Valeria Varas, poetisa, exiliada, comunicación personal, 6 de diciembre, 2016)

Entonces, en efecto, entre los elementos sobresalientes del análisis exiliar se distinguen: los acontecimientos; las funciones de los actores; el espacio u escenario del hecho; el tiempo, el motivo y el destino (o fin) del discurso; los diversos puntos de vista, sus enfoques o miradas; las tonalidades y matices que se intercalan adornando, subrayando, fortaleciendo o difuminando la narrativa, así como la afinidad del mismo ejercicio de la pertenencia del discurso y las ideas, con su participación política, de identidad, de afectividad, entre otros.

De esta forma, también lo deja entrever Alonso Venegas, productor y actor exiliado, al decir con tono enfático:

Soy tico, pero jamás voy a olvidar donde nací cuando me dicen Chile. A los países en el mundo entero, no los hacen ni las cordilleras, ni el mar; los hacen la gente y yo aprendí eso hace mucho tiempo. Lo aprendí en Costa Rica, porque no puedo exigirle a nadie que piense o hagan lo mismo que yo. (Alonso Venegas, exiliado, comunicación personal, 30 de marzo, 2017)

En los discursos suele ser palpable que, aunque el enfoque del pasado resulta conflictivo, a él se refieren, en competencia entre la memoria y la historia: "porque la historia no siempre puede creerle a la memoria, y la memoria desconfía de una reconstrucción que no ponga en su centro a los derechos del recuerdo (derecho de vida, de justicia, de subjetividad)", según describe Beatriz Sarlo (2007, p. 09). Sobre esta evocación de exilio-memoria-historia repercuten algunas notorias sensaciones; evidencias como la que reconoce la académica exiliada Paula Santander (Comunicación personal, 13 de junio, 2017):

Chile es un país doloroso, que yo quiero mucho, pero es un país que duele por todo, no solo por el exilio, por el golpe de Estado, porque es un país que le cuesta la memoria, le cuesta todavía recordar, está como muy traumado, aparte por todas las catástrofes naturales que ha tenido ...entonces es un país que cuando yo lo veo, lo veo con ternura, me duele; pero es totalmente otro país si lo comparo con mi (historia) mi infancia. 


\section{Aportes discursivos}

El exilio tiene su lugar en la memoria; cuenta la historia tácita, la no dicha y, mucho menos, la escrita a cabalidad. Sin embargo, esta narrativa ha tendido a popularizarse desde su sacralidad mítica; su comprobación mimética es cada vez más evidente, dadas las modalidades de exclusión social actuales. Las experiencias sensoriales y emotivas dan cabida al pensamiento y la interpretación.

Como un ejemplo, la captación del estado de shock, durante el conflicto chileno en el 73, fungió como uno de los elementos detonantes para las condiciones sociales de enajenación que muchos chilenos exiliados perciben hasta la actualidad. Su reinvención está contantemente presente en algunas variaciones del discurso de seguridad nacional. Incluso, Chile conserva alguna retórica en su Constitución Política desde tiempos de Pinochet.

Según replica el lingüista T. van Dijk (2012), los entretejidos del poder contienen cañones discursivos como la desinformación, el desvanecimiento de ideas culturales y el uso de la información para la represión. La retórica del poder se ampara y se reinventa discursiva y semióticamente desde la intensión estratégica del control y dominio, mediante la abstracción falsa de creencias sociales y en donde todos los sentidos se vuelven al miedo, al placer, al hedonismo... De lo anterior, resulta axiomático el discurso oficial que Augusto Pinochet, dio el 13 de septiembre de 1995, que proclama: "El pasado nos divide, que sólo el futuro y el destino común puede reunirnos y reconciliarnos. Es lo único que debemos hacer. Tenemos que olvidar". El propio dictador lo proclamó públicamente con motivo del $22^{\circ}$ aniversario del golpe militar: "Es mejor quedarse callado y olvidar".

De esta manera, discursos de olvido se entretejen al juego del poder. Según acota el filósofo exiliado Helio Gallardo (2017), esto haría que cualquier cosa internalice las condiciones de conciencia; lo cual, en el tema de los derechos humanos, consiste en que sus subjetividades no sean capturadas, saturadas por el mismo sistema ${ }^{3}$.

Igualmente, es oportuno aportar que, aunque el término-concepto de exilio ${ }^{4}$ se corresponda con muchos nombres en la actualidad; los efectos, métodos y consecuencias del fenómeno se han tornado muy intensos, notorios y expandidos globalmente. Po tanto, la reconceptualización del significado "exilio" se dice y se desdice en las nuevas afrentas al sujeto.

3 Helio Gallardo. Conferencia Inaugural Estado de derecho, y derechos humanos en América Latina. Martes 1 de noviembre de 2016. Universidad Nacional. Heredia, Costa Rica.

4 Mario Oliva en "Los nombres del exilio" esboza frases como vivir en tierra ajena, alejado, trasterrado, desterrado, descielados, entre otros adjetivos. 
En el caso chileno, afloran los testimonios de exiliados con recuerdos que validan la incrustación de una represión, porque permanece intacta en sus cuerpos, sus territorios y pensamientos. Cada recuerdo que el exiliado utiliza para contar sus vivencias está impregnado de imágenes de dolor, muerte, separación, tortura, entre otras formas de enajenación propias del ser. Así, el recuerdo en el momento del golpe de Estado concuerda con remembranzas imborrables:

Mi padre estuvo desaparecido, en el sentido que uno no sabe dónde está y posteriormente estuvo 13 meses en campos de concentración; estuvo entre Salomón y Ritoque. El 5 a septiembre de 1975 fue expulsado de Chile con 116 compañeros presos políticos. (Ingrid Behm, enfermera, hija del doctor Hugo Behm Rosas, comunicación personal, 31 de marzo, 2017)

En segunda instancia, previo al suceso, algunos hablan de sus pensamientos políticos y participaciones directas o indirectas en las izquierdas chilenas; otros hablan de sus roles comunes personales más cotidianos, por ejemplo:

Fui afortunada junto con otros compañeros de no saber lo que era pasar por la pena de no tener trabajo, directamente entré a la universidad, ahí estuve hasta el golpe de estado, fui actriz de planta de la Universidad de Chile, tuve la oportunidad de trabajar con un director alemán en una obra que se llama "El señor Portilla y su criado Martí". (Rosita Zúñiga, actriz, comunicación personal, 4 de noviembre, 2016)

Posterior a la expulsión, ellos y ellas hablan de su respectivo exilio y éxodo; momentos de recepción o acogida; manifestaciones de solidaridad; reclamos al régimen militar; la transferencia de aprendizajes; las formas de agradecimiento cultural y los aportes sustantivos efectuados al país receptor; las intenciones por regresar a Chile, los intentos e impedimentos; las decisiones para permanecer; situaciones de añoranza y melancolía; afectación a la salud mental, los dramas psicológicos por separaciones familiares y estatus profesionales; recuerdos de las consecuencias físicas de sus represiones, que aún persisten; momentos de agrado como reencuentros en el exilio.

Llegué a Costa Rica poco antes de Semana Santa en 1974, recuerdo muy bien porque fue una de las Semanas Santas que más disfruté en mi vida; fue con un amigo que había sido Secretario General de las Juventudes Socialistas...y lo encontré aquí en Costa Rica; casualmente el mismo día que yo llegué. (Pedro Urra, exdiputado, asilado político, comunicación personal, 1 de noviembre, 2016)

Entre los discursos más recientes, los exiliados hablan sobre las nuevas ideas para pensar Chile (aprendizajes y recomendaciones); la mutación de sus pensamientos como forma de resiliencia, sostén y crecimiento personal; el rol que jugaron en la 
transformación social, política y militante desde sus nuevos lugares de convivencia; la espera extensa de la caída de régimen dictatorial; los relatos que experimentaron al regresar a Chile; las sensaciones del establecimiento permanente fuera de su país natal; la lucha por las reivindicaciones legales en el marco ético por los derechos humanos; la persecución a la impunidad; pasadas y actuales formas de sociabilidad interculturales; los aportes realizados, y el papel de las mujeres.

Precisamente, de las mujeres exiliadas se distingue un afán aleccionador que abarcó desde los temas familiares hasta las contemplaciones políticas del pasado y el presente. Entre ellas, Ana María Arenas, cantante y enfermera exiliada (Comunicación personal, 22 de febrero, 2017) señala:

Al resto de los chilenos que nunca han salido del país y tienen una actitud un poco deplorable; les digo que aprendan sin necesidad de vivir la experiencia del exilio, porque la experiencia es dura, dejar a los tuyos... yo conocí a mucha gente que dejó a toda su familia allá y se vinieron solos, dejar a los tuyos, a tus amigos... es muy duro, para aprender así; que a final de cuentas todos somos seres humanos iguales y que valemos lo mismo.

Entretanto, del ámbito familiar de la mujer, se reconoce una orientación social distinta sobre vivir las consecuencias de un exilio; como lo relata la psicóloga Dina Krauskopt (Comunicación personal, 26 de mayo, 2017):

Primero estaba totalmente decidida a quedarme en Costa Rica, no pensaba ir a Chile mientras gobernaba Pinochet jamás. Yo pensé que no me iba más a Chile, mis dos hijos entraron a la educación pública, tuvieron una recepción maravillosa por parte de la orientadora, ellos estuvieron muy contentos en ese colegio. A los 9 años de estar casada, tuve a mi hija que nació aquí en Costa Rica, yo ya tenía 40 años.

\section{Narración, enfoques, miradas}

La configuración narrativa como testimonio contiene algunos rasgos particularidades. El testimonio es un relato en primera persona, que atestigua lo visto y oído (lo sentido), cuyo discurso constituye un elemento de prueba que ayuda a decir una verdad. En la mayoría de relatos observados, el rol en el narrador pasa de una posición de testigo a ser rol protagonista (yo vi, a mí me paso...). Esta posición sobresale al describirse la ejecución de acciones o decisiones tomadas:

Yo entré a la embajada y fue todo un escándalo a nivel nacional. Por la tele y los periódicos le preguntaban al embajador que quién era yo. Y qué era lo que había pasado. Me asociaban con el atentado que mató al paco. (Patricio Arenas, actor, exiliado, comunicación personal, 11 de noviembre, 2017) 
El rol protagonista se ancla en conocer ampliamente la historia, mejor que nadie; y su referencia y contenido narrativo suele ser muy profundo, abundante y hasta eclipsante. Por su parte, el testimonio suele describir el contexto, la situación y los hechos propios acontecidos y de terceras personas. Generalmente, su fidelidad tiende a ser hecho de comprobación.

Normalmente, los testimonios suelen acompañarse de cartas, álbumes personales, diarios y objetos que evocan la plasmación de un recuerdo muy íntimo o personal. Sin generalizar, se observa que a este tipo de narración se adscriben los exiliados que tuvieron una afección grande sobre sus cuerpos. Discurso y experiencia se encuentran en los siguientes relatos:

Periódicamente nos pasaban al segundo piso de interrogatorio de tortura, ahí nos desnudaban, nos sentaban en el piso, nos golpeaban los oídos... a mí me subieron dos veces, me interrogaron muchísimo, las torturas más que nada eran por mi condición de dirigente político y porque andaban en la búsqueda de unos equipos de comunicación que se habían extraviado en esos días en el instituto de Desarrollo Agrario de Chile (INDAC). (René Altamirano, sindicalista, exiliado, comunicación personal, 10 de abril, 2017)

Las narrativas del exilio desvanecen los límites de la observación entre sentir lo ajeno, sentir en carne propia y exteriorizar las críticas, opiniones y aprendizajes de la situación en conflicto:

Se creó la Comisión RETTIG ${ }^{5}$, entonces los compañeros que habíamos sido detenidos, torturados, exiliados, los familiares de aquellos que están desaparecidos hasta el día de hoy, que fueron fusilados, presentaron sus testimonios ante esta Comisión; y yo la presente desde acá (Costa Rica), desde la embajada de Chile en San José. Ellos pensaron que, con ciertas garantías económicas miserables, nos van a pagar todos los años de tortura física y psíquica, secuelas que uno arrastra hasta el día de hoy, pensaron que podían comprar nuestras conciencias. Al menos a mí no y a muchos compañeros tampoco. (Francisco Muñoz Escalona, músico y filósofo exiliado, comunicación personal, 28 de abril, 2017)

Cabe recalcar que hubo otros casos de sujetos que, en su relato, explicaban más sus pareceres, sus puntos de vista; dibujaban un panorama (casi omnipresente); realizaban sus análisis; hacían conjeturas e hipótesis, recogiendo hechos, hilando lo que se oía y lo que se veía en esos momentos, algo acorde con la posición de narrador

5 La Comisión Nacional de Verdad y Reconciliación fue creada en 1990 (mediante Decreto Supremo 355 del Ministerio de Interior) con el objetivo de contribuir al esclarecimiento de las principales violaciones de los derechos humanos cometidas entre el 11 de septiembre de 1973 y el 11 de marzo de 1990. 
deficiente ${ }^{6}$. Se corresponden con esta categoría, aquellos exiliados que tuvieron una afección distante, algo menos personal y dolorosa que otros que sí sufrieron la tortura en carne propia. Estos también mantenían una posición más discreta o menos expuesta respecto a su participación política. Se incluyen como observadores cercanos que vivieron el periodo nuclear de crisis.

Por otra parte, cuando se mira el todo como un sistema diverso y, a la vez, común a los hechos, con las distintas voces se logra desfragmentar el fenómeno sociológico y es posible buscar una conformación discursiva de la experiencia exiliar; revisar las metonimias de su lenguaje y su adscripción a las imágenes originarias que le dieron lugar suelen ser factores claves del análisis.

Por lo tanto, no se trata de encontrar las polaridades en el lenguaje sobre lo cognoscible; como sería el caso de los antónimos. El retrato, dado como un tira y encoge, le confiere al decir un hallazgo de nuevos significandos. Ciertamente, la intencionalidad de cada acto condiciona las semánticas en cada discurso; sin embargo, también se induce a un nacimiento epistémico en el que se contemplan esas distintas versiones de discurso.

Esa búsqueda debe ir siempre más allá del fantasma de la duplicación, según menciona Clement Rosset (2007), aunque existe un interés propiamente filosófico, éste es también no anecdótico; es mirar desde el primer plano. Así, las versiones retóricas - no dualistas - descritas en primera persona o en primer plano contienen a otras claves en la construcción del exiliado en su subjetividad. Entre ellas, subyacen situaciones de la vivencia tales como la vulnerabilidad, el desasosiego, el trauma, la inestabilidad, el desapego.

En los exiliados, la lectura de sus oralidades contiene una palabra sonora, textual, gestual y experiencial que revive un presente y actúa mediante sus posibilidades críticas. En estos casos, no solo enuncian sus vivencias; también enfatizan su protesta personal y como colectivos o grupos de presión?

La interpretación que podemos encontrar de sus testimonios son variantes acaecidas por la influencia lógica de su desterritoralidad (situación contextual) y por la atemporalidad del hecho que hoy describen (un hoy revisado a cuatro décadas del

6 El narrador deficiente es un testigo que relata lo que percibe a través de sus sentidos, sin emitir opiniones acerca de lo que está presenciando. Su narración es similar a la imagen proporcionada por una cámara de vídeo, ya que muestra al lector una escena determinada, sin incluir subjetividades. El narrador deficiente conoce menos aspectos de la trama, en comparación con las vivencias del protagonista. De sitio web: https://www.lifeder. com/narrador-deficiente/

7 Incluso actualmente, esta comunidad diaspórica en Costa Rica es contestaria y crítica del rumbo político y social de su país natal. 
suceso exiliar original). Por todo, entonces cabe mencionar que para la memoria, el "hoy" resulta fundante y el "yo" le da su sentido o rol protagonista.

\section{Figura 2}

Acto de protesta al gobierno de Piñera Embajada de Chile en San José y Corte Internacional de Derechos Humanos, 24 de octubre, 2019

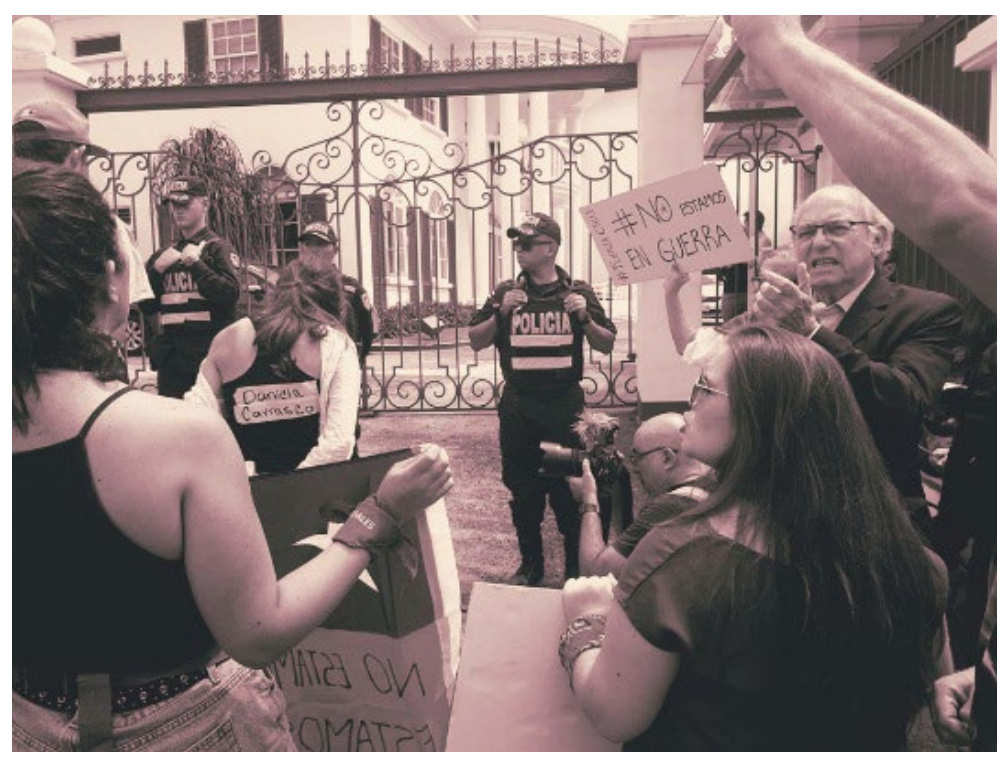

Fuente: Achivo del proyecto Voces y rostros del exilio chileno en Costa Rica, año 2019.

Por otra parte, cabe resaltar que en las narraciones del exilio se observan marcados y finos entretejidos vocales-textuales que logran hilar relatos como aproximación de la memoria a elementos de ficción que pueden dar cabida a un anhelo, a la búsqueda de una sensación utópica reconfortante, a mostrar una imagen fuerte-resiliente, y que, en ciertos casos, hasta es casi cercana a la epopeya o la novela épica ${ }^{8}$ (Valles Calatrava). En otros contextos esa mirada nuclear, casi ficcional, reviste, de un sentido especial, las memorias en su testimonio:

Escuché que alguien daba la orden de que pasaran las balas de sus fusiles mientas yo seguía caminando hacia los cerros. Recuerdo que en ese momento solamente

8 El discurso testimonial siempre intentará entregar la versión verdadera de un hecho social frente a su auditor virtual; por otro lado, el cuento o la novela, ejemplos del discurso literario o ficcional, subordinarán el relato de las acciones a su intención estética en la búsqueda de nuevos modos literarios (Maldonado Opazo, 2005) 
pensaba: “Mátenme ya, mátenme ya!” (Tatiana Tregueart, trabajadora social, exiliada, comunicación personal, 24 de marzo 2017 falta fecha de entrevista)

De la experiencia anterior, ahora la misma protagonista constata su situación actual al reflexionar:

Con toda esta experiencia, me considero una sobreviviente, una persona fuerte para enfrentar determinadas cosas, pero también me he hecho una persona con poca tolerancia a la deslealtad, a la traición, a la violencia, a la injusticia, al autoritarismo, a la verticalidad; a todo lo que tenga que ver con imponer sufrimiento y dolor a otra persona de una manera tan arbitraria. (Tatiana Tregueart, exiliada, comunicación personal, 24 de marzo 2017)

Cabe recalcar que el sentido literario casi ficcional de hechos reales dado a través del testimonio en los exiliados alude a una función moral y educativa. Como relato contiene, además, un sentido de moraleja indeleble (Valles Calatrava, 2008).

Asimismo, es mediante la recopilación de las voces; el uso de expresiones, gesticulaciones, interjecciones...que la revisión del lenguaje permite aterrizar las ideas a la memoria. Señala Gusdorf (1976, p. 61) que "ante hechos como la angustia, la tortura, o la muerte solo quedaría la expresión del grito como el último intento desesperado invocado en el supremo llamado de la conciencia mediante la eficacia mágica de su clamor". Este tipo de plasmación puede ser encontrada en acercamientos como el descrito a continuación:

A mí me da dolor y yo lloro, y lloro las veces que sean necesarias. Y lloro también con mis amigas chilenas que han pasado situaciones similares. Lo hablo y lo lloro, pero no lo comparto más porque no quiero aportar dolor a mis hijos. No quiero que ellos sepan qué le pasó a su madre porque a ellos eso no les aporta nada, ni pueden hacer nada. Yo les aporto información general del país, de lo que sufrimos para que aprendan... Pero el sufrimiento específico mío no es algo que quiero que ellos tengan porque eso se vuelve resentimiento, quiero que la experiencia se vuelva fuerza y conocimiento para ellos, para que esas cosas no vuelvan a ocurrir nunca más. (Comunicación personal, anónima)

Como presencias en exilio, la acción de sus experiencias contiene además una relación ineludible con el momento presente, en tanto que puede ser referenciado desde las prácticas emocionales y afectivas percibidas; como ejemplo, los actos de gozar o de sufrir. 
Por otra parte, para comprender el exilio en sus discursos, se necesita hacer esbozos de comprensión mutua para cogenerar actos de conciencia; son esos actos reflejos y recíprocos, intersubjetivos, en donde los aprendizajes son reconocibles; las miradas se devuelven hacia el relator y las lecciones de su testimonio son contenidas:

Uno no siente que está dando, uno simplemente da. Entonces; ¿cómo tener conciencia del aporte que yo he hecho? Ustedes me lo están dando a conocer ahora; haciéndome esta entrevista; pero, ¿de conciencia que yo haya aportado?, no lo sé porque siempre di lo mejor de mí, siempre di la milla extra en todo lo que he hecho y ese es mi aporte (risas); entregarme el $100 \%$ y ser yo siempre. (Rosita Zúñiga, exiliada, comunicación personal, 4 de noviembre, 2016)

Lo anterior dibuja un asunto de percepción doble y mutuo sobre la construcción del discurso. Como acto de confirmación, en el testimonio también se invocan las cualidades de la observación en cuanto a su veración ${ }^{9}$ intersubjetiva; es decir, de un movimiento fluyente en el que compartimos nuestros saberes con otros en el mundo de la vida según acota Rizo (2005).

Aplicar lo anterior al discurso-memoria del exilio resalta cuestiones de interés común como la persistencia del exiliado por buscar un presente en presencia para sostener su decir y que ese decir cogenere conciencia desde el acto fiable del testimonio.

\section{Filtro semiótico}

Según la narratología de Gerald Prince (1982, p. 12\#), las prácticas de "contar, rememorar son parte intrínseca en la llamada diégesis". Es decir, poder sustraer al mundo presente a la propia exposición del relato y que esta exposición responda a la descripción fiable del acontecimiento ocurrido. En el aprendizaje de los exilios, las imágenes adquiridas miméticamente no mueren tan rápidamente; al contrario, éstas se resguardan y sobresalen a través del recuerdo a la acción expositiva como memorias.

Con los procesos semióticos se nos permite identificar las bases sustantivas de la comunicación; sin embargo, ésta no se basta a sí misma como disciplina para delimitarse a explicar textos. Lingüísticamente, emplea en el discurso la codificación de un modo del decir, del uso de los lenguajes afines a la experiencia estudiada, así como el propio acto comunicativo del habla en la práctica de oralidad recopilada. Parafraseando a Parra (2014, en mención a F. de Saussure) sobre la lengua como sistema

9 Irreveración es el mantenimiento persistente en una verdad más allá de sus propios límites, ha sido, evidentemente, una de las fuentes más copiosas de ilusión y desilusión a través de toda la historia y en cualquier fase de la vida. "La veración" debe verse como un movimiento fluyente" (Bohmautoría, 1993, p. 30). 
sígnico enuncia que los signos y el lenguaje permiten una coreografía perceptiva que oscila entre lo sensible y lo inteligible ${ }^{10}$.

Cabe señalar que la semiótica es todavía un campo de estudio muy inexplorado y que posee gran potencial para generar importantes hallazgos desde su interpretación para el estudio del exilio, además sirve para identificar patrones de convencionalismo o excepción, y para discutir la simbiosis entre los hechos presentados en el discurso de la memoria (como presencialidad testimonial) y sus eventuales representaciones ${ }^{11}$.

Asimismo, el antevenir natural, pragmático y complementario de la imagen, se basa en la experiencia. Como experiencia de exilios, la práctica de la oralidad acude aún más a su razón inicial más profunda y elemental: una semiosis del exilio. En consecuencia, el valor de este tipo de análisis desde la imagen - como uso epistemológico, enfoque o metodología - redimensiona el estudio del exilio y lo compagina para su comprensión.

El análisis semiótico funciona, además, cuando las palabras no son expresas. El sentido de la experiencia se recoge en imágenes y resulta un material invaluable para desfragmentar los procedimientos del discurso, conocer su texto-contexto y los devenires específicos de su temporalidad.

Partir de que la revisión de cada rasgo, gesto, cualidad del movimiento; de cada frase, sonido o situación de silencio reflejaría el encadenamiento de una situación que irradia una sensación presente ineludible para los sujetos que se aprestan al mensaje.

Sensaciones como miedo, enfado, cólera, terror, sorpresa, pesadumbre, entre otras, son algunas expresiones visibles en el lenguaje corporal (Ramírez. 2016). Esta fuerza ilocutiva del discurso depende de la mímica, los gestos y los aspectos no articulados del relato, según expone Paul Ricoeur (1995). En este caso, los elementos prosódicos ${ }^{12}$ o sonoros se desplazan por la fuerza ilocutiva o gestual del discurso.

Como se observa, la memoria es un acto discursivo ${ }^{13}$ que responde, desde la semiótica, a los elementos visibles (signados) y a aquellos que consideramos de primera mano como invisibles o poco identificables (los imaginados).

10 En La imagen y esfera semiótica (Juan Diego Parra Valenzuela, 2014año).

11 Presentar se refiere ejecutar la acción, decir un testimonio, obtener de primera mano la experiencia. Representar se da en la generación de una mimesis; tiende a confundirse con remedar, imitar, alegorizar.

12 Derivación de la lingüística que analiza y representa formalmente aquellos elementos de la expresión oral tales como el acento, los tonos y la entonación.

13 Los discursos contienen actos locutivos, ilocutivos y perlocutivos. 
En cuanto a las imágenes del exilio, los símbolos compilados recuerdan señales del propio ADN como los significados de lucha, de conflicto, expulsión, sobrevivencia, interacción cultural, éxodo y acogida; espacios de sociabilidad, paisajes, relaciones familiares, trabajo, sitios de encuentro, manifestaciones, peñas, entre otros. También están aquellas primeras impresiones sensitivas de sus exilios, que se comprueban con los objetos guardados de su experiencia, los álbumes familiares, viejos baúles, entre otros.

\section{Figura3}

\section{El baúl de los recuerdos}

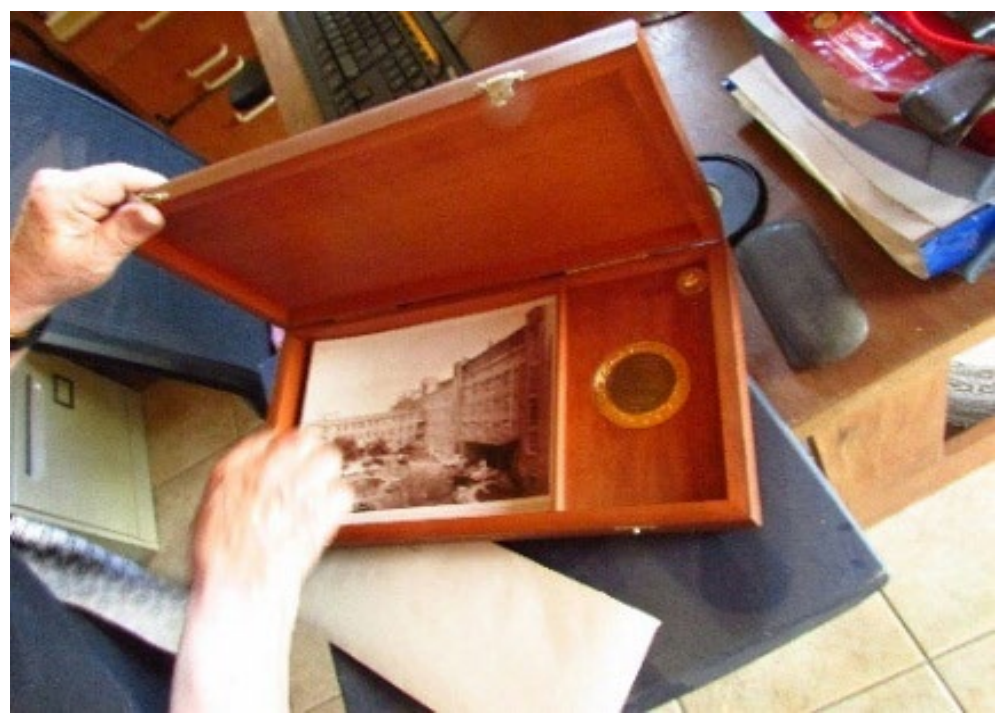

Fuente: Archivo del proyecto Voces y rostros del exilio chileno en Costa Rica.

Sin lugar a dudas, la imagen se recubre de acciones. elementos de utilidad discursiva tales como: la acción, la imaginación, el movimiento, la costumbre, la creencia, el valor, la conducta, los rituales, los sueños, las ideas, los deseos y los elementos acaecidos en el No deseo (como la inacción) que también hablan. La imagen contiene lo que se dice y lo que NO se dice, como las miradas, reacciones gestuales, las sensaciones producidas, inquietudes, ignorancias, los olvidos, los actos de inhibición, represión, silencio, ocultamiento y negaciones.

El imaginario colectivo en las memorias del exilio promueve una validación de convencionalismos sobre los aconteceres, palabras y significados que se describen; imágenes que se anclan desde la afectividad, los sentimientos y las sensaciones 
vividas. La memoria es el elemento catalizador y disparador del eterno vivir, contiene el resultado frenético de lucha entre recuerdo y olvido. Tales situaciones provocan una serie de excitaciones críticas por redescubrir que, para el abordaje del exilio, no se pueden obviar.

\section{En conclusión}

- Los estudios del discurso y sus componentes semióticos son importantes activos para el análisis del exilio en sus vertientes con la memoria. Su revisión pedagógica evidencia cualidades de uso como teoría, fuente, recurso e instrumento para el estudio de las narrativas testimoniales.

- La desfragmentación lingüística y semiótica de los relatos testimoniales ilustra, valida, demuestra, confirma o desmiente el entretejido de las percepciones, interacciones e imaginaciones en la construcción del discurso exiliar.

- Pensar el exilio conlleva abstraer y sustraer elementos de indagación constantes en tiempos y espacios; el exilio como objeto de estudio es maleable, dinámico, se nutre de imágenes sociales y mentales que conllevan un trasfondo difícil de abarcar. El exilio no se resuelve; sin embargo, las comprensiones presentadas aportan nuevas miradas al entretejido cultural en sus procesos de inter-subjetivación.

- La revisión a fondo de las memorias del exilio es un ejercicio de responsabilidad ética con las victimas que experimentan procesos de exclusión semejantes en cualquiera de sus diversas manifestaciones. Iniciar por concebir el reconocimiento de sus problemas, luchas y movimientos permite adquirir los aprendizajes necesarios para evitar los riesgos en repetir la historia.

\section{Referencias}

Bohm, David. (1993). La totalidad y el orden implicado. España: Editorial Kairós.

Camacho Monge, Daniel. Comunicación personal, 30 de marzo 2017.

Campos Santelices, Armando. Comunicación personal, 21 de abril de 2017.

Franco, Marina. (Enero-junio, 2007). Sentidos y subjetividades detrás del discurso: Rreflexiones sobre las narrativas del exilio producidas en entrevistas orales. Sevilla, España: Anuario de Estudios Americanos, 64, 1, enero-junio, 37-62.

Gallardo, Helio. (1, noviembre, 2016). Conferencia Inaugural Coloquio Estado de dDerecho, y derechos humanos en América Latina [Conferencia Inaugural].. Martes 1 de noviembre de 2016. Universidad Nacional. IDELA. Heredia, Costa Rica. 
Gusdorf, Georges. (1971). La Palabra. Buenos Aires, Argentina: Ediciones Nueva Visión.

Maldonado Opazo, Kira. (2005). El discurso testimonial en las autobiografías de chilenos exiliados en Suecia. Universidad de Chile.

Narváez, Ángelo. Arte y exilio chileno en Costa Rica. Una entrevista a Mario Oliva Medina. 27 de julio de 2019. Sitio razacosmica.cl

Parra, Juan Diego. (2014) La ilmagen y la esfera semiótica. Bogotá, Colombia: Revista ICONOFACTO, Vol. 10. (No. 14), \#76-\#89.

Prince, Gerald. (1982). Narratología. La forma y el funcionamiento de la narrativa. Roma: Pratiche Edtitrice.

Ramírez Caro. (2016). Como analizar de todo. Heredia, Costa Rica: EUNA.

Ricoeur, Paul. (1995). Teoría de la Interpretación. Madrid, España: Siglo XXI Editores.

Ricoeur, Paul. (2000). La memoria, la historia, el olvido. Madrid, España: Editorial Trotta.

Rizo, Marta. (2005). La intersubjetividad como eje conceptual para pensar la relación entre comunicación, subjetividad y ciudad. México: Razón y Palabra, revista digita n.47. octubre-noviembre . En Revista digital Razón y Palabra. sitio http://www.razonypalabra.org.mx/anteriores/ n $47 /$ mrizo.html.

Rosset, Clement. (2007) El Objeto singular. México DF.: Editorial Sexto Piso.

Santander, Paula. Comunicación personal, 13 de junio, 2017.

Santos, B. de S. (2009). Una epistemología del Sur: La reinvención del conocimiento y la emancipación social. México: Siglo XXI, CLACSO.

Sarlo, Beatriz. (2005) Tiempo pasado. Cultura de la memoria y giro subjetivo. Una discusión. Siglo veintiuno editores.

Valles Calatrava, José. (2008). Teoría de la narrativa. Una perspectiva sistemática. Iberoamericana. Nuevos Hispanismos.

Teun A. Van Dijk, Teun A.. (2012). Discurso y contexto. Barcelona. España: Gedisa. 